UDK: 636.32/.38.09:616.831

Research article

\title{
SCRAPIE RESISTANCE GENE IDENTIFICATION USING OPTIMIZED TAQMAN TEST QPCR METHOD IN SHEEP ON THE TERRITORY OF THE REPUBLIC OF SERBIA
}

\author{
Slađan NEŠIĆC ${ }^{1 a *}$, Stefan JELISIĆ ${ }^{2 a}$, Sanja ALEKSIĆ-KOVAČEVIĆ ${ }^{1}$, \\ Milan ANIČIĆ ${ }^{1}$, Ivana VUČIĆEVIĆ ${ }^{1}$ \\ ${ }^{1}$ Department of Pathology, Faculty of Veterinary Medicine, University of Belgrade, \\ Bul. oslobodjenja 18, Belgrade, Serbia; ${ }^{2}$ Phd student, Faculty of veterinary medicine, University of \\ Belgrade, Bul. oslobodjenja 18, Belgrade, Serbia
}

(Received 27 April, Accepted 11 June 2021)

\begin{abstract}
Scrapie is an infectious neurodegenerative disease affecting the central nervous system of sheep and goats that belongs to transmissible spongiform encephalopathies. The disease is caused by the accumulation of proteinase-resistant isoform of the prion protein. The sheep predisposition to scrapie is associated with polymorphisms of the PrP gene. Genetic susceptibility to scrapie is mainly related to codons 136, 154, and 171. ARR sheep are strongly scrapie resistant and VRQ genotype is the most susceptible. Many countries have scrapie eradication programs based on using rams with resistant genotype. The eradication program has not yet been implemented in the Republic of Serbia. To examine the genetic makeup of sheep in Serbia related to scrapie, we optimized TaqMan probes of real-time polymerase chain reaction (qPCR) technique for three codons. Blood samples from 100 sheep were analyzed by qPCR and the majority of the examined sheep were AA homozygous for the 136 codon. For codon 154 the most frequent genotype was RR and for codon 171 the most frequent genotype was QQ.
\end{abstract}

Key words: genotyping, polymorphisms, qPCR, Scrapie, TaqMan probes

\section{INTRODUCTION}

Scrapie is a fatal, neurodegenerative disease of sheep and goats belonging to the group of transmissible spongiform encephalopathies (TSEs). As with other diseases in this group, the causative agent is a prion. Although monitoring has been conducted for years in many countries, scrapie is still endemic in many parts of the world [1]. It does not pose a direct risk to human health, but there is a hypothesis that bovine spongiform encephalopathy (BSE) in the United Kingdom in the '90s was the result of the passage of a scrapie-like agent into the cattle population [2]. Scrapie can cause serious economic

*Corresponding author: e-mail: sladjan@vet.bg.ac.rs

${ }^{a}$ These authors contributed equally to the manuscript 
consequences that include individual producer losses, as well as export losses that affect the entire country. Infectious prions are cellular prion proteins misfolded into an abnormal protease-resistant isoform (PrPSc) by an unknown mechanism [3,4]. Oral exposure seems to be the main route of PrPSc entry, but infection may also occur after ocular exposure or contact with injured skin or mucous membranes [5,6]. After oral exposure, PrPSc accumulates in the gut-associated lymphoid tissues (GALT) and can be detected in the tonsils, spleen, and retropharyngeal and mesenteric lymph nodes for months before reaching CNS [7]. During that time, infected sheep can shed the agent into the environment via body fluids including placental fluids, milk and colostrum resulting in vertical transmission to newborns, as well as horizontal transmission within the flock at the time of lambing [8].

The susceptibility of sheep to scrapie and the incubation period depend on polymorphism of the prion protein gene $(p r n p)$ that encodes the cellular protein and the nature of the prion strain. Three major sites in prnp associated with sheep resistance to classic scrapie are at codons 136, 154, and 171 [9]. Each allele is marked with a three-letter code and the ARR allele is associated with a highly protective effect against infection with classical scrapie but does not provide resistance towards atypical scrapie [8]. Atypical scrapie is not an infectious disease and appears sporadically as a degenerative brain disease in elderly sheep [6]. Susceptibility to classical scrapie is associated with valine $(\mathrm{V})$, arginine $(\mathrm{R})$ and glutamine $(\mathrm{Q})$ on codons 136, 154 and 171 respectively, while alanine $(A)$, histidine $(H)$ and arginine $(\mathrm{R})$ on the same codons provide resistance $[8,10,11]$. The most common haplotypes are ARR, ARQ, AHQ, ARH and VRQ [12]. The ARR haplotype is considered to have the lowest risk for classical scrapie under natural conditions. Sheep with this allele are highly unlikely to carry or transmit scrapie. However, some data suggest that ARR/ARR sheep cannot be considered fully resistant to classical scrapie, but such infections are extremely rare $[9,13]$. The prnp polymorphism in sheep has been used for years as a basis for scrapie eradication programs conducted in many countries. In the UK the scrapie disease control program by genotyping started in the 1990s. The main goal of the eradication programs is to minimize the theoretical risk of scrapie to public health using genetically most resistant rams for mating to increase the frequency of ARR alleles and reducing the frequency of risk alleles. In the long run, the program should contribute to the control and elimination of scrapie. In the USA the implementation of the scrapie eradication program had the effect of reducing the number of scrapie positive sheep at the slaughter line by $90 \%[8,14]$.

There are just a few diagnosed cases of scrapie in sheep in the Republic of Serbia. However, due to occasional outbreaks of scrapie in countries in the region, it is necessary to perform genotyping of sheep in the Republic of Serbia in order to increase the level of genetic resistance to TSEs in the national sheep flock. 


\section{MATERIAL AND METHODS}

\section{Sampling}

In this study, the blood of 100 sheep from the territory of the Republic of Serbia (farms from Progar and Svilajnac) was tested. All sheep were of the Württemberg breed and clinically healthy, as determined by a veterinarian examination before blood sampling. Sheep blood samples were taken by puncture of v. jugularis in the amount of $3 \mathrm{ml}$ in vacutainers with EDTA as an anticoagulant and transported to the laboratory where they were stored in a refrigerator at $6^{\circ} \mathrm{C}$ until the moment of DNA isolation.

\section{DNA extraction from blood}

Invitrogen PureLink kit was used to isolate DNA from sheep blood. Genomic DNA was extracted from $50 \mu$ l of whole blood according to the manufacturer's instructions (Applied Biosystems, Thermo Fisher Scientific). DNA was resuspended in $50 \mu 1$ or $100 \mu \mathrm{l}$ of elution buffer. Extracted DNA samples were stored at $4^{\circ} \mathrm{C}$ until use.

Since the blood clotted in a certain number of samples, the isolation procedure was started by combining part of the clot $(600 \mu \mathrm{l})$ and PBS in tubes with ceramic beads. After addition, the tubes were centrifuged at $6,500 \mathrm{Rpm}$ for 40 seconds at room temperature. Thereafter, the further isolation procedure was the same as mentioned above.

Table 1. Sets of primers and probes for the determination of sheep prnp alleles [11]

\begin{tabular}{|c|c|c|}
\hline \multirow{4}{*}{$\begin{array}{c}136 \\
(\mathrm{~A} / \mathrm{V})\end{array}$} & Primers & PrP-136F: 5'-GCCTTGGTGGCTACATGCT-3 \\
\hline & & PrP-136R: 5'-CGGTCCTCATAGTCATTGCCAAAAT-3 \\
\hline & Probes & PrP-136-Ala-VIC: 5'-CTCATGGCACTTCC 3 \\
\hline & & PrP-136-Val-FAM: 5'-CTCATGACACTTCC 3 \\
\hline \multirow{4}{*}{$\begin{array}{c}154 \\
(\mathrm{R} / \mathrm{H})\end{array}$} & Primers & PrP-154 F: 5'-TGGCAATGACTATGAGGACCG-3 \\
\hline & & PrP-154 R: 5'-TGGTCTGTAGTACACTTGGTTGGG-3 \\
\hline & Probes & PrP-154-Arg-FAM:5'-ACTATCGTGAAAACAT-31 \\
\hline & & PrP-154- His-VIC: 5'-TACTATCATGAAAACATG-3 \\
\hline \multirow{4}{*}{$\begin{array}{c}171 \\
(\mathrm{R} / \mathrm{Q})\end{array}$} & Primers & PrP-171F: 5'-ACCCCAACCAAGTGTACTACAGA-3 \\
\hline & & PrP171R: 5'-GTCATGCACAAAGTTGT'TCTGGT-3 \\
\hline & Probes & PrP-171-Gln-VIC: 5'-CCAGTGGATCAGTATAGT-3' \\
\hline & & PrP-171-Arg-FAM: 5'-CAGTGGATCGGTATAGT-3 \\
\hline
\end{tabular}




\section{Determination of codon 136, 154 and 171 polymorphisms (qPCR, TaqMan assay)}

Polymorphism determination of codons 136, 154 and 171 was performed on a StepOne ${ }^{\mathrm{TM}}$ Real-Time PCR System (Applied Biosystems, Thermo Fisher Scientific). Oligonucleotide sequences and probes, for codon differentiation 136, 154 and 171 were designed by the commercial service (Assay by Design Service, Applied Biosystems) for prnp genes in sheep. Primers for each codon were marked: one with fluorescent dye (VIC) and the other with FAM. Tubes with a volume of $0.5 \mathrm{ml}$ were prepared for each codon. In each tube were added: $2.7 \mu \mathrm{l}$ of DNAse free water, $5 \mu \mathrm{l}$ of polymerase (TaqMan Universal Master Mix, Applied Biosystems, Thermo Fisher Scientific), appropriate probes 1 and $2-0.2 \mu \mathrm{l}$ and $0.45 \mu \mathrm{l}$ of each primer $(\mathrm{F}, \mathrm{R})$. This mixture was transferred to a well on a PCR plate and $1 \mu$ l of DNA isolated was added. Quantitative PCR (qPCR) amplification was performed using the TaqMan method in a $10 \mu \mathrm{l}$ reaction. Amplification was performed according to the manufacturer's instructions (Applied Biosystems).

\section{RESULTS}

\section{PrP genotypes of sheep}

The frequency of $\operatorname{PrP}$ genotypes tested on 100 sheep from the territory of the Republic of Serbia, based on codons 136, 154 and 171 is shown in Table 2.

Table 2. The frequency of PrP genotypes

\begin{tabular}{ccc}
\hline PrP genotype & N & \% \\
\hline ARQ/ARQ & 34 & 34 \\
\hline ARR/ARQ & 29 & 29 \\
ARR/ARR & 6 & 6 \\
\hline AHQ/AHQ & 10 & 10 \\
ARQ/AHQ & 18 & 18 \\
\hline VRQ/VRQ & 1 & 1 \\
\hline ARQ/VRQ & 2 & 2 \\
Total & 100 & 100 \\
\hline
\end{tabular}

$\mathrm{N}$ - number of sheep

By analyzing the prnp gene polymorphisms, we found that two polymorphisms occur at each codon. Codon 136 contains alanine (A) and alanine/valine (A/V), codon 154 arginine $(\mathrm{R})$ and arginine/histidine $(\mathrm{R} / \mathrm{H})$ and codon 171 glutamine $(\mathrm{Q})$ and glutamine/arginine (Q/R) (Table 3). 
The ARQ allele was the most prevalent, and the predominant genotype was ARQ/ ARQ. Sheep with ARR/ARQ genotype form the second most represented group in this study. The VRQ/VRQ genotype is very rare and has been reported in only one case. Sheep with ARR/ARR genotype are considered the most genetically resistant, which was recorded in 6 cases.

Table 3. Polymorphisms of codons 136,154 and 171

\begin{tabular}{cccc}
\cline { 2 - 4 } & 136 & 154 & 171 \\
2 & $\mathrm{~A}$ & $\mathrm{R}$ & $\mathrm{Q}$ \\
$\mathrm{A} / \mathrm{V}$ & $\mathrm{R} / \mathrm{H}$ & $\mathrm{Q} / \mathrm{R}$ \\
\hline
\end{tabular}

According to the National Scrapie Plan of Great Britain (NSP) [15], depending on the genotype, the sheep are divided into groups according to sensitivity, i.e. resistance to scrapie, which is shown in Table 4.

Table 4. Different levels of sensitivity base on genotypes of sheep

\begin{tabular}{cc}
\hline & N \\
NSP 1 & 6 \\
NSP 2 & 28 \\
NSP 3 & 55 \\
NSP 4 & $/$ \\
NSP 5 & 3 \\
\hline
\end{tabular}

NSP1 - Sheep that are genetically most resistant to scrapie, NSP2 - Sheep that are genetically resistant but need careful selection for further breeding, NSP3 - Sheep that are genetically poorly resistant to scrapie (requires very careful selection), NSP4 - Sheep that are genetically susceptible to scrapie and which should not be used for breeding, NSP5 - Sheep that are genetically most sensitive and which should not be used for breeding [15].

The most characterized polymorphisms occur at codons 136, 154, and 171, with genotype VRQ being the most susceptible and ARR the most resistant. The established genotype shows that the examined sheep mostly belong to the group that is not particularly genetically resistant to scrapie, so it is necessary to focus on selective breeding in order to minimize the risk of developing this disease.

\section{DISCUSSION}

Determination of prnp gene polymorphisms in sheep is performed worldwide, with more than 80 breeds of sheep in Europe, the Americas, and Asia examined [16]. According to data obtained from the sheep scrapie control program in the United Kingdom, all genotypes except the ARR/ARR genotype belong to groups of sheep that are susceptible to scrapie. 
This is the first study regarding the examination of genetic makeup of sheep related to scrapie susceptibility conducted on a sheep population in the Republic of Serbia. Our results showed that only $6 \%$ of the examined sheep have the ARR/ARR genotype, which is related to genetic resistance to scrapie. The ARQ/ARQ genotype was present in 34\% of the examined sheep, the ARR/ARQ genotype in 29\%, the ARQ/AHQ genotype in 18\%, and the AHQ/AHQ genotype in 10\%, while the ARQ/VRQ and VRQ/VRQ genotypes were present in the smallest percentage (ARQ/VRQ - 1\%, VRQ/VRQ - 2\%).

The most frequent genotype was ARQ/ARQ and it is already known as the most common haplotype. Sheep with ARQ/ARQ genotype are susceptible to scrapie, but not all exposed sheep of this genotype get scrapie and if they do, usually have a long incubation period and prolonged survival [17]. Genotyping in the neighboring countries has also shown that ARQ is present with a high frequency: in Bosnia and Herzegovina it is present with 64.29\% in Pramenka sheep breed [18], in Croatia it is present with $67.4 \%$ in the Istrian sheep breed [19], in the Hungarian breed Tsigai at $53.45 \%$ [20], etc.

Research conducted by Baylis et al. (2004) shows that the risk of developing scrapie in British breeds is highest in sheep with the VRQ/VRQ genotype. However, the frequency of this genotype is very rare. The ARR/ARR genotype was observed in $21 \%$ of sheep, the ARQ/ARQ genotype in $12 \%$ of sheep, the ARR/ARQ genotype in $28 \%$ of diseased sheep, the ARQ/AHQ genotype in $6 \%$ of sheep, and the AHQ/ AHQ genotype in 1\% of sheep [21].

According to Groschup et al. (2007) research performed on German breeds has shown the prevalence of ARR/ARR genotype was 35.4\%, ARQ/ARQ genotype $16.9 \%$, ARR/ARQ genotype - 46.7\%, ARR/VRQ genotype - 0,7\% and an average of $0.1 \%$ in sheep with ARQ/VRQ, ARR/AHQ and ARQ/AHQ genotypes [9].

De Andrade et al. (2013) in their research analyzed blood of 3 Brazilian sheep breeds. In all analyzed breeds, the majority of the animals were AA homozygous for the 136 codon. The most frequent genotype for codon 154 was RR, and genotypes QQ and QR were the most frequent for codon 171 [22].

The established genotype shows that the examined sheep mostly belong to the group that is not particularly genetically resistant to scrapie, so it is necessary to focus on selective breeding in order to minimize the risk of developing this disease.

Although no case of scrapie has been registered in the last ten years, the obtained results indicate that the examined sheep population has genetically little resistance to classical scrapie. However, susceptibility to this disease should be considered individually for each breed, given that there are differences in the susceptibility of sheep with the same genotypes, so the authors plan to broaden the study in order to analyze all Serbian indigenous breeds of sheep. Sheep genotyping is very important to conduct in order to increase the level of genetic resistance to scrapie that would also 
enable the reduction and eventually eradication of the scrapie. These measures would also indirectly protect the public health from the potential BSE cases.

\section{Acknowledgement}

The study was supported by the Ministry of Education, Science and Technological Development of the Republic of Serbia (Contract number 451-03-68/2020-14/200143) and by the Republic of Serbia, Inovation Fund (Contract number 706).

\section{Authors' contributions}

All authors carried out the molecular genetic studies. SN, SJ and IV drafted the manuscript. SN, SAK, MA and IV participated in the design of the study. All authors read adn approved the final manuscript.

\section{Declaration of conflicting interests}

The author(s) declared no potential conflicts of interest with respect to the research, authorship, and/or publication of this article.

\section{REFERNCES}

1. O'Rourke KI, Baszler TV, Besser TE et al: Preclinical Diagnosis of Scrapie by Immunohistochemistry of Third Eyelid Lymphoid Tissue, J Clin Microbiol. 2000, 38(9): 3254-3259.

2. Konold T, Lee YH, Stack MJ et al: Different prion disease phenotypes result from inoculation of cattle with two temporally separated sources of sheep scrapie from Great Britain, BMC Vet Res. 2006; 2: 31.

3. Prusiner SB. Molecular biology of prion diseases. Science 1991, 252(5012):1515-1522.

4. Gough KC, Maddison BC: Prion transmission: prion excretion and occurrence in the environment. Prion 2010, 4(4):275-282.

5. Glaysher BR, Mabbott NA: Role of the GALT in scrapie agent neuroinvasion from the intestine. J Immunol 2007, 178:3757-3766.

6. Acín C, Bolea R, Monzón M, Monleón E, Moreno B, Filali H, Marín B, Sola D, Betancor M, Guijarro IM, García M, Vargas A, Badiola JJ: Classical and atypical scrapie in sheep and goats. Review on the etiology, genetic factors, pathogenesis, diagnosis, and control measures of both diseases. Animals (Basel) 2021, 11(3):691.

7. Orge L, Lima C, Machado C, Tavares P, Mendonça P, Carvalho P, Silva J, Pinto ML, Bastos E, Pereira JC, Gonçalves-Anjo N, Gama A, Esteves A, Alves A, Matos AC, Seixas F, Silva F, Pires I, Figueira L, Vieira-Pinto M, Sargo R, Pires MDA: Neuropathology of animal prion diseases. Biomolecules 2021, 11(3):466. 
8. Greenlee JJ: Review: update on classical and atypical scrapie in sheep and goats, Vet Pathol 2019: 56(1):6-16.

9. Groschup MH, Lacroux C, Buschmann A, Lühken G, Mathey J, Eiden M, Lugan S, Hoffmann C, Espinosa JC, Baron T, Torres JM, Erhardt G, Andreoletti O: Classic scrapie in sheep with the ARR/ARR prion genotype in Germany and France. Emerg Infect Dis 2007, 13(8):1201-1207.

10. de Andrade CP, de Oliveira EC, Leal JS, de Almeida LL, de Castro LA, Da Silva SC, Driemeier D: Report of outbreaks of classical scrapie in Dorper sheep and associated prion protein gene polymorphisms in affected flocks. Trop Anim Health Prod 2015, 47:1203-1212.

11. Zabavnik J, Cotman M, Juntes P, Ambrozic I: A decade of using small-to-medium throughput allele discrimination assay to determine prion protein gene (Prnp) genotypes in sheep in Slovenia. J Vet Diagn Invest 2018, 30:144-149.

12. Dobly A, Van der Heyden S, Roels S: Trends in genotype frequency resulting from breeding for resistance to classical scrapie in Belgium (2006-2011). J Vet Sci 2013, 14(1):45-51.

13. Leal JS, De Andrade CP, Correa GLF, Boos GS, Bianchi MV, da Silva SC, Lopes RFF, Driemeier D: Classical scrapie diagnosis in ARR/ARR sheep in Brazil. Acta Sci Vet 2015, 43,69:1-7.

14. USDA APHIS: National scrapie surveillance plan. Ft. Collins, CO; 2010

15. Warner R, Morris D, Dawson M: PrP genotype progression in flocks participating in the National Scrapie Plan for Great Britain. Vet Rec 2006, 159:473-479.

16. Goldmann W, Baylis M, Chihota C, Stevenson E, Hunter N: Frequencies of PrP gene haplotypes in British sheep flocks and the implications for breeding programmes. J Appl Microbiol 2005;98:1294-1302.

17. Laegreid WW, Clawson ML, Heaton MP, Green BT, O’Rourke KI, Knowles DP: Scrapie resistance in ARQ sheep. J Virol 2008, 82(20):10318-10320.

18. Zečević E, Dokso A, Kazic A, Brka M: Polymorphisms of ovine prion protein $(\mathrm{PrP})$ gene in Pramenka sheep breed population in Bosnia and Herzegovina. Turk J Vet Anim Sci 2015, 39:537-542.

19. Cubric-Curik V, Feligini M, Ferencakovic M, Alen Dzidic A,Salajpal K, Ambriovic-Ristov A, Cetkovic H , Majhen D, Curik I: Sequence polymorphism of PrP exon 3 gene in Istrian and crossbred sheep. Ital J Anim Sci 2009, 8:86-88.

20. Lühken G, Lipsky S, Peter C, Erhardt G: Prion protein polymorphisms in autochthonous European sheep breeds in respect to scrapie eradication in affected flocks. Small Rumin Res 2008, 75:43-47.

21. Baylis M, Chihota C, Stevenson E, Goldmann W, Smith A, Sivam K, Gravenor, MB: Risk of scrapie in British sheep of different prion protein genotype. J Gen Virol 2004, 85:27352740 .

22. de Andrade CP, Almeida LL, de Castro LA, Driemeier D, da Silva SC: Development of a real-time polymerase chain reaction assay for single nucleotide polymorphism genotyping codons 136, 154 and 171 of the prnp gene and application to Brazilian sheep herds, J Vet Diagn Invest 2013, 25(1):120-124. 


\title{
IDENTIFIKACIJA OPTIMIZOVANOM TAQMAN PROBOM QPCR METODOM GENA REZISTENCIJE NA SCRAPIE KOD OVACA NA TERITORIJI REPUBLIKE SRBIJE
}

\author{
Slađan NEŠIĆ, Stefan JELISIĆ, Sanja ALEKSIĆ-KOVAČEVIĆ, \\ Milan ANIČIĆ, Ivana VUČIĆEVIĆ
}

Ovčija svrabež je infektivno neurodegenerativno oboljenje iz grupe transmisivnih encefalopatija koje uzrokuje promene u moždanom tkivu ovaca i koza. Oboljenje je uzrokovano akumulacijom proteinaza-rezistentne izoforme prion proteina. Osetljivost ovaca na ovo oboljenje uslovljena je polimorfizmom PrP gena. Genetska otpornost na ovčiju svrabež prevashodno je uslovljena kodonima 136, 154 i 171. Najotpornije su ovce sa ARR genotipom, dok se ovce sa VRQ genotipom smatraju najosetljivijim. Mnoge zemlje su sprovele programe eradikacije ovčije svrabeži bazirane na korišćenju priplodnih ovnova koji imaju rezistentan genotip. Ovakav program još nije sproveden u Republici Srbiji. U cilju ispitivanja genetskog statusa ovaca u Srbiji u pogledu otpornosti na ovčiju svrabež, optimizovali smo TaqMan probu, kvantitativne lančane reakcije polimeraze (qPCR) tehnike za sva tri kodona. Ispitivanjem uzoroka krvi od 100 ovaca primenom RT-PCR ustanovljeno je da je većina ovaca AA homozigot za kodon 136. Za kodon 154 najčešći genotip je RR, a za kodon 171 genotip QQ. 